doi: $10.1017 /$ S2040174417000149

\title{
Reduced fetal vitamin D status by maternal undernutrition during discrete gestational windows in sheep
}

\author{
J. K. Cleal ${ }^{1}$, M. R. Hargreaves ${ }^{1}$, K. R. Poore ${ }^{1}$, J. C. Y. Tang ${ }^{2}$, W. D. Fraser ${ }^{2,3}$, M. A. Hanson ${ }^{1}$ and L. R. Green ${ }^{1}$ * \\ ${ }^{1}$ Institute of Developmental Sciences, Faculty of Medicine, University of Southampton, Southampton, Hampshire, UK \\ ${ }^{2}$ Department of Medicine, Norwich Medical School, University of East Anglia, Norwich, Norfolk, UK \\ ${ }^{3}$ Norfolk and Norwich University Hospital, Norwich, Norfolk, UK
}

\begin{abstract}
Placental transport of vitamin D and other nutrients (e.g. amino acids, fats and glucose) to the fetus is sensitive to maternal and fetal nutritional cues. We studied the effect of maternal calorific restriction on fetal vitamin D status and the placental expression of genes for nutrient transport [aromatic T-type amino acid transporter-1 (TAT-1); triglyceride hydrolase/lipoprotein uptake facilitator lipoprotein lipase (LPL)] and vitamin D homeostasis [CYP27B1; vitamin D receptor (VDR)], and their association with markers of fetal cardiovascular function and skeletal muscle growth. Pregnant sheep received $100 \%$ total metabolizable energy (ME) requirements (control), 40\% total ME requirements peri-implantation [PI40, 1-31 days of gestation (dGA)] or 50\% total ME requirements in late gestation (L, 104-127 dGA). Fetal, but not maternal, plasma 25-hydroxy-vitamin D (25OHD) concentration was lower in PI40 and L maternal undernutrition groups $(P<0.01)$ compared with the control group at 0.86 gestation. PI40 group placental CYP27B1 messenger RNA (mRNA) levels were increased $(P<0.05)$ compared with the control group. Across all groups, higher fetal plasma 25OHD concentration was associated with higher skeletal muscle myofibre and capillary density $(P<0.05)$. In the placenta, higher VDR mRNA levels were associated with higher TAT-1 $(P<0.05)$ and LPL $(P<0.01)$ mRNA levels. In the PI40 maternal undernutrition group only, reduced fetal plasma $25 \mathrm{OHD}$ concentration may be mediated in part by altered placental CYP27B1. The association between placental mRNA levels of VDR and nutrient transport genes suggests a way in which the placenta may integrate nutritional cues in the face of maternal dietary challenges and alter fetal physiology.
\end{abstract}

Received 18 November 2016; Revised 9 February 2017; Accepted 13 February 2017; First published online 22 March 2017

Key words: fetus, nutrient transport, placental, undernutrition, vitamin D

\section{Introduction}

Poor nutrition in pregnancy and fetal adaptive responses are linked to increase the risk of chronic diseases in later life, including diabetes and cardiovascular disease. ${ }^{1}$ The placenta is the only route for nutrients, including 25 -hydroxy-vitamin $\mathrm{D}$ (25OHD), to reach the fetus from the mother; it is an important factor in determining the nutrient 'signal' received by the fetus.

Restriction of maternal metabolizable energy intake in pregnant sheep, even when during isolated critical windows of development, is linked to altered cardiovascular control during fetal $^{2-8}$ and adult life. ${ }^{4,9}$ Fetal sheep skeletal muscle myofibre and capillary density in late gestation were reduced following maternal undernutrition in either early or late gestation. ${ }^{10}$ Periconceptional or preimplantation maternal undernutrition disrupted the expression in fetal sheep skeletal muscle of genes regulating myoblast proliferation, differentiation and protein synthesis, insulin signalling and associated microRNA (miRNA). ${ }^{11,12}$ While the effect of macronutrient deficiency on fetal cardiovascular control and growth has been

*Address for correspondence: L. R. Green, Institute of Developmental Sciences, University of Southampton, 887 Southampton General Hospital, Coxford Road, Southampton, Hampshire SO16 6YD, UK.

(Email: L.R.Green@soton.ac.uk) characterized, ${ }^{2-8}$ there is very little information on the role played by specific micronutrients such as vitamin $\mathrm{D}$. The micronutrient vitamin $\mathrm{D}$ comes from diet (ergocalciferol, $\mathrm{D}_{2}$; cholecalciferol, $\mathrm{D}_{3}$ ) or the action of sunlight on skin (cholecalciferol, $\mathrm{D}_{3}$ ). Both forms are hydroxylated in the liver to $25 \mathrm{OHD}_{2}$ or $25 \mathrm{OHD}_{3}$ (together in this paper they are referred to as $\left.25 \mathrm{OHD}_{\text {total }}\right)$. Maternally derived $25 \mathrm{OHD}$ is converted to 1,25-dihydroxy-vitamin $\mathrm{D}\left(1,25(\mathrm{OH})_{2} \mathrm{D}\right)_{2}$ or $\mathrm{D}(1,25(\mathrm{OH})$ $2 \mathrm{D})_{3}$ by $1-\alpha$-hydroxylase (CYP27B1) in the fetal kidney and placenta. ${ }^{13-15}$ The enzyme 24- $\alpha$-hydroxylase (CYP24A1) breaks down $25 \mathrm{OHD}$ and $1,25(\mathrm{OH})_{2} \mathrm{D}$ to $24,25(\mathrm{OH})_{2} \mathrm{D}$ and $1 \alpha-24,25(\mathrm{OH})_{2} \mathrm{D}$, respectively.

Vitamin D is linked to many aspects of physiology in health and disease, including calcium homeostasis and bone health, the cardiovascular system and skeletal muscle, although its potential role in fetal development is debated. ${ }^{16-18}$ The vitamin $\mathrm{D}$ receptor (VDR) is present in a wide range of tissues, including heart, vasculature and skeletal muscle. ${ }^{19-21}$ The physiological effects of vitamin D may operate across the life course, and these effects may start in utero. ${ }^{22,23} \mathrm{~A}$ total of $5-70 \%$ of pregnant women are vitamin $\mathrm{D}$ deficient $(<20-50 \mathrm{nmol} / \mathrm{l}$, 25OHD), depending on skin pigmentation, latitude, diet and the seasons that are traversed by the pregnancy. ${ }^{24}$ There is evidence to suggest that vitamin $\mathrm{D}$ deficiency during pregnancy is linked to altered cardiovascular function in rat 
offspring postnatally, ${ }^{25-27}$ and to human muscle development in childhood (4-6 years). ${ }^{28,29}$ However, there is very limited information on whether materno-fetal vitamin $D$ status is associated with cardiovascular control and growth during fetal life, and to our knowledge there is no information under conditions of restricted maternal nutrition.

In order to reach the fetus, vitamin $\mathrm{D}$, mostly in the 25OHD-form, must be transported across the placenta. Vitamin D may be one of the cues about maternal and fetal nutrient status to which the placenta responds by changing its growth and nutrient transport (e.g. of amino acids, fats and glucose) in order to support optimal fetal growth. ${ }^{30}$ In mice, maternal $25 \mathrm{OHD}$ deficiency reduced the diameter of the lumen of fetal blood vessels in the placental labyrinth and was associated with increased fetal weight and lower body weight at day 14 postnatally. ${ }^{31}$ In humans, higher maternal $25 \mathrm{OHD}$ concentrations in the latter half of gestation were associated with higher placental CYP27B1 protein levels, suggesting that maternal $25 \mathrm{OHD}$ regulates placental production of $1,25(\mathrm{OH})_{2} \mathrm{D}^{32}$ Furthermore, fetal levels of $25 \mathrm{OHD}$ and $1,25(\mathrm{OH})_{2} \mathrm{D}$ may regulate placental VDR expression. ${ }^{33}$ Interestingly, placental VDR expression is decreased in fetal growth-restricted pregnancies ${ }^{34}$ and increased in diabetic pregnancies. $^{35}$ Therefore placental adaptations to poor nutrition could impact on fetal 25OHD status even if the mother is not herself deficient in $25 \mathrm{OHD}$, however this idea has not been investigated directly to date in an animal undernutrition model.

The placenta may integrate nutritional cues in the face of maternal undernutrition or vitamin $\mathrm{D}$ deficiency by vitamin D-mediated transcriptional regulation [via vitamin $\mathrm{D}$ response elements (VDREs)] of placental genes involved in nutrient transport and growth. One such gene is the insulin receptor $(\mathrm{IR})^{36}$ and VDREs have been identified within its promotor region. ${ }^{37,38}$ Placental amino acid transport is vital for fetal growth $^{39,40}$ and in pregnancies from the Southampton Women's Survey, maternal serum 25OHD and vitamin D-binding protein concentrations were correlated with the expression of specific placental amino acid transporters. ${ }^{41}$ A potential VDRE exists 1040 base pairs upstream from the start of exon one of the human T-type amino acid transporter-1 (TAT-1) gene, slc16a10 (Simner C. \& Cleal J.K., unpublished results, MatInspector ${ }^{(}$1998-2014 Genomatix Software $\left.\mathrm{GmbH}^{42}\right)$. In the human genome following stimulation with calcitriol, a VDR-binding site was identified in the slc16a6 gene which, like TAT-1 (slc16a10), is a member of the solute carrier family 16. ${ }^{43}$ Placental lipases, such as lipoprotein lipase (LPL), release fatty acids from maternally derived triglyceride for transport to the fetus Placental LPL activity increases towards term and is responsive to a maternal high-fat diet. ${ }^{44,45}$ Upregulation of LPL gene expression by vitamin $\mathrm{D}$ is suggested by a positive association between human serum LPL and 25OHD concentrations, ${ }^{46}$ increased LPL gene expression in cultured adipocytes in response to $1,25(\mathrm{OH})_{2} \mathrm{D},{ }^{47}$ and the identification of a partial VDRE in the rat LPL gene promotor region. ${ }^{48}$
In our previous work, the fetal cardiovascular control and growth adaptations to maternal undernutrition were not associated with a change in placental weight or blood flow. ${ }^{2,3}$ However, placental amino acid or fatty acid transport, and their regulation by maternal-fetal vitamin $\mathrm{D}$ and the placental VDR, could be involved.

There is very little information on the interactions between vitamin D, the placenta and fetal cardiovascular control and growth. To address these gaps in knowledge, we used an established sheep model of fetal physiology to investigate whether maternal undernutrition during critical windows of gestation altered the expression of genes regulating or sensing vitamin $\mathrm{D}$ in the placenta, altered fetal vitamin $\mathrm{D}$ status and decreased the expression of genes involved in placental growth and nutrient transport. Furthermore, we investigated potential mechanistic links by examining the relationships between placental growth and nutrient transporter gene expression, placental VDR gene expression and materno-fetal vitamin D status, as well as the relationship between fetal plasma $25 \mathrm{OHD}_{\text {total }}$ concentration and markers of fetal cardiovascular function and skeletal muscle structure. , $10^{2}$

\section{Methods}

All procedures were carried out with local ethical committee approval (Science Review Group, a sub-committee of the Animal Welfare and Ethical Review Body) and in accordance with the UK Animals (Scientific Procedures) Act 1986.

\section{Animals and study design}

Welsh Mountain ewes (not-shorn) of uniform body condition score (BCS 2.0-3.0) and age were housed individually on wheat straw from 16 days before mating in barns at The Royal Veterinary College (Hertfordshire, UK), with no direct sunlight. After 104 days of gestation (dGA, term is 147 days) ewes were transferred to The University of Southampton Biomedical Research Facility and housed in temperature-controlled rooms on a 12 hour light/dark cycle (lamps were not sheathed to block ultraviolet wavelengths). All animals were fed the same complete pelleted diet which is supplemented as standard with vitamin $\mathrm{D}_{3}$ (Table 1. Charnwood Milling Company Ltd., Suffolk, UK) with free access to water from 16 days before conception. Vitamin D content of manufactured pelleted feed was not measured. For each ewe, the $100 \%$ metabolizable energy requirement was calculated according to Agricultural and Food Research Council guidelines on the basis of ewe weight at the start of the study, and standard gestational increases were incorporated. ${ }^{49}$ Using expected metabolizable energy levels for the feed (Table 1), the daily ration of pelleted feed for each ewe was calculated. Ewes were randomly allocated across the breeding season to one of three groups: Control animals (C) were fed 100\% of metabolizable energy requirements throughout pregnancy; peri-implantation nutrient-restricted animals (PI40) were fed $40 \%$ of metabolizable energy requirements from 1 to $31 \mathrm{dGA}$, 
Table 1. Ingredients and expected composition of sheep diet pelleted feed

\begin{tabular}{lc}
\hline & Level \\
\hline A. Ingredient & \\
Barley (\%) & 5.00 \\
Wheat (\%) & 10.00 \\
Hi-pro soya (\%) & 13.50 \\
Full fat soya meal (\%) & 5.00 \\
Grass meal (\%) & 15.00 \\
Molasses (\%) & 5.00 \\
PTS straw (\%) & 35.00 \\
Dicalcium phosphate (\%) & 0.25 \\
Limestone (\%) & 0.50 \\
Salt (\%) & 0.5 \\
Microionized wheat (\%) & 10.00 \\
Sheet vitamin/mineral supplement (\%) & 0.25 \\
B. Nutrient ${ }^{\mathrm{a}}$ & \\
Dry matter (\%) & 89.21 \\
Metabolizable energy (mj/kg dry matter) & 10.725 \\
Protein (\%) & 14.75 \\
Calcium (\%) & 0.689 \\
Phosphorus (\%) & 0.313 \\
Vitamin D 3 (IU/kg) & 2000 \\
\end{tabular}

${ }^{a}$ Levels are those expected as defined by the raw material matrix, Charnwood Milling.

and $100 \%$ at all other times; and late gestation nutrientrestricted animals (L) were fed 50\% of metabolizable energy requirements from $104 \mathrm{dGA}$ until the end of the study, and $100 \%$ at all other times. Oestrus was synchronized by withdrawal of a vaginal medoxyprogesterone acetate impregnated sponge (Veramix; Upjohn, Ltd, Crawley, UK) at -2 dGA, 14 days after insertion. One of two twin rams (randomly assigned) was introduced for 2 days, and 0 dGA was taken as the first day that an obvious raddle mark was observed. Twin pregnancies, identified by ultrasound scan at mid-gestation, were removed from the trial. Final group sizes of singleton-bearing ewes were c, $n=8$; PI $40, n=9$; and L, $n=6$.

\section{Surgery and care}

At $\sim 117 \mathrm{dGA}$, anaesthesia was induced with $1 \mathrm{~g}$ thiopental sodium BP I.V. (10 ml, $0.1 \mathrm{~g} / \mathrm{ml}$; Link Pharmaceuticals, UK) and maintained with $2 \%$ halothane (Concord Pharmaceuticals Laboratory Ltd., UK) in oxygen ( $1 \mathrm{l} / \mathrm{min})$. Ewes and singleton fetuses underwent surgical instrumentation using aseptic technique that included the insertion of heparinized polyvinyl catheters into the fetal femoral and carotid arteries, femoral vein, and the maternal jugular vein, and placement of ultrasonic flow probes (Transonic Systems Inc., Ithaca, NY, USA) around the uncatheterized carotid and femoral arteries. At surgery, antibiotics were administered to ewes (topically to incision sites, oxytetracycline hydrochloride, Pfizer, Eastleigh, Northants, UK; $150 \mathrm{mg} / \mathrm{kg}$ I.M. Betamox, Norbrook Laboratories Ltd, UK.; $600 \mathrm{mg}$ I.V. Crystapen,
Britannia Pharmaceuticals, UK; $40 \mathrm{mg}$ I.V. Gentamycin, Faulding Pharmaceuticals PLC, UK), fetuses (300 mg I.V. Crystapen) and amniotic fluid (300 mg Crystapen; $40 \mathrm{mg}$ Gentamycin). A minimum of 4 days of post-operative recovery were allowed before experimentation during which an antibiotic regime was administered (Daily, half-surgical doses of crystapen; days 1 and 2, Gentamycin surgical doses repeated) and analgesia was administered to the ewe as required $(1.4 \mathrm{mg} / \mathrm{kg}$ S.C., Carprofen, Pfizer Ltd., UK). Catheters were flushed daily with heparinized saline and their patency was maintained by a continuous infusion (fetal, $0.01 \mathrm{ml} /$ hour; ewe, $1 \mathrm{ml} / \mathrm{h}$ ). Blood gases were monitored daily to assess health (ABL735; Radiometer Limited, Crawley, UK).

\section{Fetal cardiovascular assessment}

As reported previously, ${ }^{2,3}$ under baseline conditions at 125-126 dGA fetal carotid artery, amniotic and tracheal pressures (Capto AS, N-3193, Horten, Norway/NL 108; Digitimer Ltd, Welwyn Garden City, UK), ECoG (NL 100/104/125) and carotid and femoral arterial blood flows (TS420; Transonic Systems Inc.) were captured (sampling rate 40 samples/s, Maclab/8; ADInstruments Pty Ltd, Castle Hill, Australia) and recorded (Chart; ADInstruments, Chalgrove, UK). Fetal heart rate (beats/min) was calculated from peaks on the pulsatile blood pressure recording.

As previously reported, ${ }^{3}$ blood flow was measured in combined maternal and fetal portions of a representative type $\mathrm{B}$ placentome with fluorescent microspheres under baseline conditions at $125 \mathrm{dGA}$. The type A placentomes are concave and consist of mainly maternal tissue, type $\mathrm{D}$ placentomes are convex and consist of fetal tissue completely surrounding maternal tissue, and types $\mathrm{B}$ and $\mathrm{C}$ are intermediate in shape. ${ }^{50,51}$ In brief, reference blood samples were withdrawn $(2.06 \mathrm{ml} / \mathrm{min})$ continuously from femoral and carotid artery catheters $10 \mathrm{~s}$ before, during ( $40 \mathrm{~s})$ and after $(75 \mathrm{~s})$ the injection of microspheres into the femoral vein catheter (Molecular Probes, PoortGebouw, The Netherlands). Microspheres circulate for $<1$ min. $^{52}$ Placental tissue and reference blood were collected into a processing unit (SPU; Gaiser Kunststoff und Metallprodukte, Kappel-Grafenhausen, Germany) and digested ( $4 \mathrm{M}$ aqueous $\mathrm{KOH}$ with $2 \%$ Tween-80, covered with a $1.5 \mathrm{ml}$ layer of isopropanol)..$^{53}$ The microspheres were then washed with phosphate buffer, dissolved with $4 \mathrm{ml}$ cellosolve ${ }^{\circledR}$ acetate (Sigma-Aldrich Inc., UK), and analysed (LS-55 luminescence spectrometer; PerkinElmer Inc., UK). LS-55 settings were adjusted to ensure that excitation and emission wavelengths of each fluorophore were separated and the 'spill' between dyes kept to $<2 \%$. A process control microsphere was added to each sample and reference filter to confirm no loss in digestion and dissolution steps. The intra-assay coefficient of variation for the process control was $6.7 \%$.

Organ blood flows were calculated with the formula:

$$
\text { Blood flow }=\left(100 / \mathrm{Wt}_{\text {sample }}\right) \times\left(\mathrm{Wd}_{\text {ref }} \times\left(F_{\text {sample }} / F_{\text {ref }}\right)\right),
$$


where blood flow is in $\mathrm{ml} / \mathrm{min} / 100 \mathrm{~g}$ tissue, $\mathrm{Wt}_{\text {sample }}$ is the weight of the tissue sample, $\mathrm{Wd}_{\text {ref }}$ the withdrawal rate of the reference sample, $F_{\text {sample }}$ the fluorescence intensity of the tissue sample and $F_{\text {ref }}$ the fluorescence intensity of the reference sample. ${ }^{52}$

Just before killing the ewe and fetus at $127 \pm 0.2 \mathrm{dGA}$ [ $40 \mathrm{ml}$ I.V. $200 \mathrm{mg} / \mathrm{ml}$ Pentoject (pentobarbitone sodium), Animalcare Ltd, UK], maternal and fetal femoral arterial blood was collected into cold heparinized syringes for immediate analysis of ionized calcium $\left(\mathrm{Ca}^{2+}\right)$ (ABL735; Radiometer Limited, Crawley, UK). A further sample of maternal and fetal blood was collected onto chilled Lithium Heparin tubes, centrifuged at $1600 \mathrm{~g}$ and $4^{\circ} \mathrm{C}$ for $10 \mathrm{~min}$, and plasma was stored at $-80^{\circ} \mathrm{C}$. Plasma angiotensin II concentration was measured in duplicate by radioimmunoassay (Euria-angiotensin II; ImmunoDiagnostic Systems Ltd, Tyne and Wear, UK) following its separation from plasma proteins using chromatography columns (C18 sep-pak; Waters Corporation, Massachusetts, USA). The intra- and inter-assay coefficients of variation were 8.0 and $7.5 \%$, respectively. Ang II levels were measured in plasma $(0.5 \mathrm{ml}) .^{2}$ Type B placentomes were frozen in liquid nitrogen and stored at $-80^{\circ} \mathrm{C}$.

\section{Skeletal muscle immunohistochemistry}

Mid-belly samples of triceps brachii muscle were frozen in freezing isopentane and $10 \mu \mathrm{m}$ transverse sections were cut for assessment of myofibre and capillary density by immunohistochemistry, as described in full in. ${ }^{10}$ In brief, primary antibodies were used to were positively identified fast (type II) myofibres (monoclonal mouse anti-skeletal fast myosin antibody, 1:100, clone MY32; Sigma, USA) and capillary endothelial cells (polyclonal rabbit anti-human von Willebrand factor (1:300; DakoCytomation, Denmark) with biotinylated anti-mouse (1:400) or anti-rabbit (1:400) secondary antibodies, streptavidin-biotin-peroxidase complex $(1+1: 200)$ and amino ethyl carbazole treatment. Sections for myofibre analysis were counterstained with Mayers haematoxylin. Negative controls for the primary antibody were processed simultaneously. Five microscopic images $(40 \times$ objective) were captured from each stained section (one per primary antibody per animal) which was validated as a good representation of overall myofibre density (error $<4.8 \%$ ) and capillary density $(<5.7 \%$ error). In each image the total fascicular area was calculated and was the area in which myofibre and capillary density was assessed. Using a non-biased counting frame, all myofibres (red stained fast-twitch and negatively stained white slow myofibres) were counted; myofibre density was expressed as the number of fibres per square millimetre of fascicle. Capillary density was expressed as capillary number per square millimetre of fascicle. All measurements were made by one observer and (intraobserver variability $<5 \%$ for all variables).

\section{OHD analysis}

The concentration of $25 \mathrm{OHD}_{2}$ and $25 \mathrm{OHD}_{3}$ (when combined is termed total circulating $25 \mathrm{OHD}\left(25 \mathrm{OHD}_{\text {total }}\right)$ was determined in maternal and fetal lithium heparin plasma samples by high performance liquid chromatography tandem mass spectrometry (LC-MS/MS). ${ }^{54} 25 \mathrm{OHD}_{2}$ and $25 \mathrm{OHD}_{3}$ were extracted by isotopic dilution protein precipitation from $100 \mu \mathrm{l}$ plasma. Following the addition of zinc sulphate, an acetonitrile solution containing hexa-deuterated $25 \mathrm{OHD}_{3}$ $[26,26,26,27,27,27,-2 \mathrm{H} 6]\left(2 \mathrm{H} 6-25 \mathrm{OHD}_{3}\right)$ was added to the samples as internal recovery standard. After centrifugation, the supernatant was injected into Sunfire C18 $3.5 \mu \mathrm{m} 2.1 \times 50 \mathrm{~mm}$ chromatography columns (Waters, UK), and $25 \mathrm{OHD}_{3}$ and $25 \mathrm{OHD}_{2}$ were separated (flow rate of $0.4 \mathrm{ml} / \mathrm{min}$ ). Potential interfering compounds were removed by gradient elution using initially $88 \%$ methanol:water which was gradually increased to $100 \%$ methanol over run time of $4.5 \mathrm{~min}$. Mass detection was performed by Ultima Pt LC-MS/MS system (Micromass, UK). ${ }^{55}$ Identification and quantification is based on multiple reaction monitoring of each analyte specific ion transitions. Quantifier transitions used were $413>271\left(25 \mathrm{OHD}_{2}\right)$, $401>383\left(25 \mathrm{OHD}_{3}\right)$, and $407>107 \quad\left(2 \mathrm{H} 6-25 \mathrm{OHD}_{3}\right)$. Qualifer ion transitions $413>395\left(25 \mathrm{OHD}_{2}\right), 401>258$ $\left(25 \mathrm{OHD}_{3}\right)$ were used to monitor each analyte, with the requirement that the quantifier/qualifier ion ratio must be within $\pm 20 \%$ for confirming the presence in samples. Assay sensitivity was determined by the lower limit of quantification: $25 \mathrm{OHD}_{3}=2.5 \mathrm{nmol} / \mathrm{l}$ and $25 \mathrm{OHD}_{2}=2.5 \mathrm{nmol} / \mathrm{l}$. Assay imprecision was assessed for both $25 \mathrm{OHD}_{2}$ and $25 \mathrm{OHD}_{3}$ over linear working range from $0-300 \mathrm{nmol} / \mathrm{l}$. The coefficient of variation $(\mathrm{CV})$ was $<10 \%$ for intra-assay precision $(n=10)$ $\left(25 \mathrm{OHD}_{3}\right.$ : mean $5.9 \mathrm{nmol} / \mathrm{l}$, S.D. $2.1, \mathrm{CV} 10.8 \%$; mean $25.49 \mathrm{nmol} / \mathrm{l}$, s.D. 2.1 , CV 8.3\%; mean $62.1 \mathrm{nmol} / \mathrm{l}$, s.D. 2.6, CV 4.1\%; mean $185.49 \mathrm{nmol} / \mathrm{l}$, s.D. 7.2 , CV 3.9\%. $25 \mathrm{OHD}_{2}$ : mean $4.5 \mathrm{nmol} / \mathrm{l}$, s.D. 1.6 , CV $8.6 \%$; mean $18.49 \mathrm{nmol} / \mathrm{l}$, s.D. 1.6, CV 8.6\%; mean $51.6 \mathrm{nmol} / \mathrm{l}$, s.D. 4.0, CV 7.7\%; mean $176.49 \mathrm{nmol} / \mathrm{l}$, S.D. $9.2, \mathrm{CV} 5.2 \%)$ and inter-assay precision $(n=10)\left(25 \mathrm{OHD}_{3}\right.$ : mean $6.0 \mathrm{nmol} / \mathrm{l}$, S.D. $0.5, \mathrm{CV} 8.3 \%$; mean $27.69 \mathrm{nmol} / 1$, S.D. 1.8 , CV $6.6 \%$; mean $63.2 \mathrm{nmol} / \mathrm{l}$, s.D. 4.1, CV 6.5\%; mean $189.59 \mathrm{nmol} / \mathrm{l}$, s.D. 9.8, CV 5.1\%. $25 \mathrm{OHD}_{2}$ : mean $4.8 \mathrm{nmol} / \mathrm{l}$, S.D. 0.4 , CV $9.0 \%$; mean $21.59 \mathrm{nmol} / \mathrm{l}$, S.D. 2.2 , CV $10.1 \%$; mean $55.5 \mathrm{nmol} / \mathrm{l}$, s.D. 3.1 , CV 5.7\%; mean 184.749 nmol/l, s.D. 9.5, CV 5.1\%).

Extraction efficiency (extraction of vitamin $\mathrm{D}$ from matrix) was assessed by determining the amount of $25 \mathrm{OHD}_{3} / \mathrm{D}_{2}$ recovered from the amount added $(50,100$ and $500 \mathrm{nmol} / \mathrm{l})$ to plasma before extraction taking into account the endogenous concentration of the plasma sample. Spiked recovery for maternal $\left(25 \mathrm{OHD}_{2}: 90.8,87.7\right.$ and $86.7 \%$, respectively. $25 \mathrm{OHD}_{3}$ : $95.6,91.2$ and $93.02 \%$, respectively) and fetal $\left(25 \mathrm{OHD}_{2}: 104.4,89.6\right.$ and $88.98 \%$, respectively. $25 \mathrm{OHD}_{3}$ : $88.4,92.8$ and $88.32 \%$, respectively).

\section{Real-time quantitative reverse transcription polymerasae chain reaction ( $q R T-P C R$ )}

Real-time qRT-PCR was carried out according to Minimum Information for Publication of Quantitative real-time PCR 
Table 2 . Primers and probes used in real-time quantitative reverse transcription polymerase chain reaction measurements

\begin{tabular}{|c|c|c|c|c|c|}
\hline Gene & Forward primer & Reverse primer & Probe & $R^{2}$ & Efficiency \\
\hline$\beta$-actin & gaggcatcctgaccctcaag & tctccatgtcgtcccagttg & ccccattgagcacggcattgtca & 0.99 & 1.9 \\
\hline GAPDH & taggctacactgaggaccaggtt & cccagcatcgaaggtagaaga & tctcctgcgacttcaacagcgacact & 0.98 & 2.1 \\
\hline IR & accgccaagggcaagac & agcaccgctccacaaactg & aactgccctgccactgtcatcaacg & 0.93 & 2.1 \\
\hline LPL & accagactccaacgtcatcgt & gcttggtgtaccctgcagaca & tcacgggcccagcagcattatcc & 0.95 & 2.0 \\
\hline VDR & gaagctgaatttgcacgaaga & gtcctggatggcctcgacc & UPL Probe $15^{\circ}$ & 0.99 & 2.0 \\
\hline TAT-1 & aagatggtcttcaagacagc & gtctgtgaagacactgacaa & UPL Probe 74 & 0.98 & 2.0 \\
\hline CYP27B1 & cgcagctgcgtggggaga & tacctcaaagtggatcaagatctg & UPL Probe 53 & 0.98 & 2.0 \\
\hline
\end{tabular}

IR, insulin receptor; LPL, lipoprotein lipase; VDR, vitamin D receptor; UPL, Universal Probe Library from Roche; TAT-1, T-type amino acid transporter-1.

Nucleotide sequence, coefficient of determination $\left(R^{2}\right)$, efficiency of primers and probes (according to MIQE guidelines).

Experiments (MIQE) guidelines in terms of methodology, validation and analysis. ${ }^{56}$ Whole type $\mathrm{B}$ placentomes consisting of maternal and fetal tissues were powdered in a frozen tissue press (C, $n=7 ;$ PI $40, n=8 ; \mathrm{L}, n=6$ ). Total RNA was extracted from $50 \mathrm{mg}$ powdered placental tissue using the mirVana $^{\text {TM }}$ miRNA Isolation Kit (Ambion ${ }^{\circledR}$, Life Technologies) according to the manufacturer's instructions. The integrity of total RNA was confirmed by agarose gel electrophoresis, and RNA concentration and purity were determined using a Nanodrop ${ }^{\mathrm{TM}}$ Spectrophotometer. Following DNAse treatment (RQ1 RNase-Free DNase, Promega) total RNA $(0.2 \mu \mathrm{g})$ was reverse transcribed with $0.5 \mu \mathrm{g}$ random hexamer primer, 200 units M-MLV reverse transcriptase, 25 units recombinant RNasin ribonuclease inhibitor and $0.5 \mathrm{mM}$ each of dATP, $\mathrm{dCTP}, \mathrm{dGTP}$ and dTTP in a final reaction volume of $25 \mu \mathrm{l}$ in $1 \times$ M-MLV reaction buffer (Promega, Wisconsin, USA). All samples were produced in one batch to reduce variation.

The messenger RNA (mRNA) levels of genes involved in vitamin D homeostasis (CYP27B1, VDR) and nutrient transport (IR, TAT-1, LPL) were measured. Intron-exon boundary spanning oligonucleotide probes and primers (Table 2) were designed using the Roche ProbeFinder version 2.45 [CYP27B1, VDR, TAT-1; Universal Probe Library probes (UPL)] and Primer 3 (LPL, IR; Taqman probes) after alignment of bovine and human mRNA sequences; followed by validation. Primer specificity was confirmed using the NCBI Nucleotide BLAST application. UPL probes were supplied by Roche and all primers plus Taqman probes were synthesized by Eurogentec (Seraing, Belgium). Using the geNorm housekeeping gene selection kit (Primer Design Ltd., Southampton $\mathrm{UK}), \beta$-actin ( $M$ value 0.69$)$ and GAPDH ( $M$ value 0.62$)$ were selected from a panel of 10 genes with $M$ values between 0.62 and 2.10. The efficiency and coefficient of determination for each primer and probe set are presented in Table 2 .

Real-time qRT-PCR was carried out using a Roche Light-Cycler-480 with LightCycler ${ }^{\circledR} 480$ Probes $2 \times$ Master Mix (Roche, West Sussex, UK) for hydrolysis probe detection (containing FastStart Taq DNA Polymerase). For UPL and Taqman probes the cycle parameters were $95^{\circ} \mathrm{C}$ for $10 \mathrm{~min}$, followed by 40 cycles of $95^{\circ} \mathrm{C}$ for $15 \mathrm{~s}$ and $60^{\circ} \mathrm{C}$ for $1 \mathrm{~min}$. For
Primer Design Perfect Probes the cycle parameters were $95^{\circ} \mathrm{C}$ for $10 \mathrm{~min}$, followed by 40 cycles of $95^{\circ} \mathrm{C}$ for $10 \mathrm{~s}$ and $60^{\circ} \mathrm{C}$ and $72^{\circ} \mathrm{C}$ for $15 \mathrm{~s}$. The intra-assay CVs for genes were $4.4-9.5 \%$. Each placental sample was run on the same plate in triplicate. Controls without reverse transcriptase enzyme and controls without template (complementary DNA) were included in each PCR assay, and these indicated no genomic DNA or other contamination. All mRNA levels were calculated using the standard curve method and were normalized to the geometric mean of the housekeeping genes $\beta$-actin and GAPDH. PCR products were checked by agarose gel electrophoresis to confirm correct amplicon size.

\section{Data analysis and statistics}

We assessed the normality (histograms, values of skewedness, the Kolmogorov-Smirnov test and normal Q-Q plots) and homogeneity of variance (Levene's test) of data. Data were transformed (natural logarithm) as required before parametric analysis. Plasma concentration of $25 \mathrm{OHD}_{3}, 25 \mathrm{OHD}_{2}$, $25 \mathrm{OHD}_{3}+25 \mathrm{OHD}_{2}\left(=25 \mathrm{OHD}_{\text {total }}\right)$ and $\mathrm{Ca}^{2+}$ concentrations were compared between mother and fetus by paired $t$-test. There was a mixture of fetal sex within the diet groups $\mathrm{C}$ (four male; four female), PI40 (five male; four female) and L (four male; two female). All variables were analysed by analysis of variance (with main factors of dietary group and fetal sex) followed by Tukey's honest significant difference post-hoc tests where appropriate (SPSS version 21, IBM). Linear regression analysis (GraphPad Prism version 6, GraphPad Software Inc.) was used to examine relationships between two factors across all dietary groups and within each group. Sample size was determined by power calculations based on mean arterial pressure, a key outcome variable from the original study. ${ }^{2,3}$ Significance was accepted when $P<0.05$, and trends defined as $0.05<P<0.1$. Data are expressed as mean \pm S.E.M.

\section{Results}

\section{Materno-fetal 25OHD and calcium}

There was no difference between dietary groups in maternal plasma $25 \mathrm{OHD}_{3}, 25 \mathrm{OHD}_{2}$ or $25 \mathrm{OHD}_{\text {total }}$ concentration 
(a)

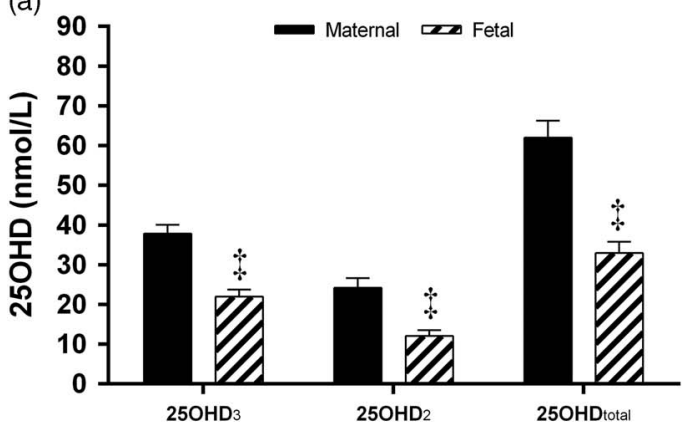

(b)

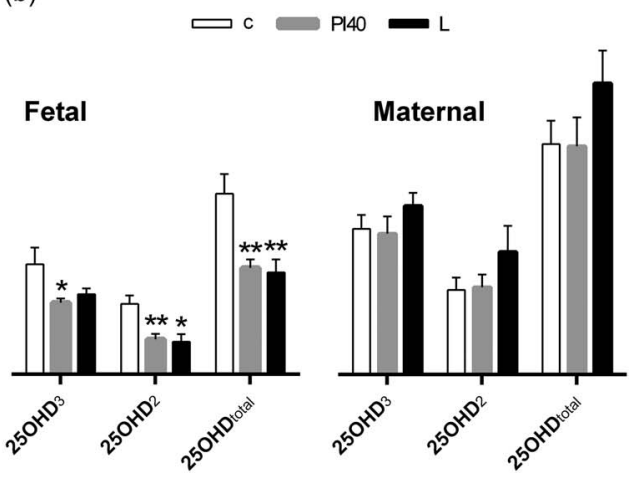

Fig. 1. Materno-fetal plasma vitamin D status in late gestation and the effect of maternal undernutrition. Values are mean \pm S.E.M. (a) Maternal (solid bars) $v$. fetal (hatched bars) concentrations of $25 \mathrm{OHD}_{3}$ and $25 \mathrm{OHD}_{2}$ forms and their combined total $(25 \mathrm{OHD}$ total $)$ ${ }^{\ddagger} P<0.0001$; (b) concentrations of $25 \mathrm{OHD}_{3}, 25 \mathrm{OHD}_{2}$ and $25 \mathrm{OHD}_{\text {total }}$ in fetus and mother in $\mathrm{C}$, control (open bars). ${ }^{*} P<0.05,{ }^{* *} P<0.01$ compared with control group. PI40, peri-implantation undernutrition (grey bars); L, late gestation undernutrition (solid bar) groups.

(Fig. 1b). Fetal plasma concentrations of $25 \mathrm{OHD}_{2}$ and $25 \mathrm{OHD}_{\text {total }}$ were lower in PI40 and L groups compared with the control group. Fetal plasma concentration of $25 \mathrm{OHD}_{3}$ was lower in the PI40 group compared with the control group.

Across all diet groups, $25 \mathrm{OHD}_{\text {total }}, 25 \mathrm{OHD}_{3}$ and $25 \mathrm{OHD}_{2}$ concentrations were greater in maternal than in fetal plasma $(P<0.0001$, Fig. 1a). In the $\mathrm{L}$ group only, higher maternal plasma $25 \mathrm{OHD}_{\text {total }}$ concentration tended to be associated with higher fetal $25 \mathrm{OHD}_{\text {total }}$ plasma concentration $\left(r^{2}=0.5839\right.$, $P=0.0769$ ). In the $\mathrm{C}$ group only, higher maternal $25 \mathrm{OHD}_{3}$ plasma concentration tended to be associated with higher fetal $25 \mathrm{OHD}_{3}\left(r^{2}=0.4912, P=0.0794\right)$.

$\mathrm{Ca}^{2+}$ concentration was not different between diet groups in either maternal (mmol/l. C: 1.19 \pm 0.02 ; PI40: 1.19 \pm 0.01 ; L: $1.17 \pm 0.04)$ or fetal (mmol/l. C: $1.23 \pm 0.05$; PI 40 : $1.27 \pm 0.04$; L: $1.29 \pm 0.03)$ blood. Across all diet groups, $\mathrm{Ca}^{2+}$ concentration was greater in fetal than in maternal blood $(P=0.027)$. There was no association between maternal and fetal blood $\mathrm{Ca}^{2+}$ concentration by linear regression. There was no association between maternal or fetal $25 \mathrm{OHD}_{\text {total }}$ plasma concentration and blood $\mathrm{Ca}^{2+}$ concentration.

\section{Placental CYP27B1 and VDR mRNA}

In the placenta, CYP27B1 mRNA levels were greater in the PI40 group compared with the control group $(P=0.048$, Fig. 2a). In the PI40 group only, lower placental CYP27B1 mRNA levels were associated with a higher maternal blood $\mathrm{Ca}^{2+}$ concentration $\left(r^{2}=-0.737, P=0.0064\right)$ and a higher placentome type B blood flow $\left(r^{2}=-0.7129, P=0.0084\right)$ (Fig. 2b).

There was no difference in placental VDR mRNA levels between dietary groups (Fig. 2a). Across all dietary groups, lower maternal plasma $25 \mathrm{OHD}_{\text {total }}$ concentration was associated with higher placental VDR mRNA levels $\left(r^{2}=-0.2683, P=0.0193\right.$, Fig. 2b). A higher fetal:maternal
$25 \mathrm{OHD}_{\text {total }}$ ratio was associated with higher placental VDR mRNA in the PI40 group only $\left(r^{2}=0.5096, P=0.0467\right)$.

\section{Placental transport and growth genes mRNA}

There was no significant difference between dietary groups in the placental mRNA levels of IR, TAT-1 or LPL (Fig. 3). Across all groups, higher placental VDR mRNA levels were associated with higher placental LPL mRNA levels $\left(r^{2}=0.471, P=0.0012\right.$, Fig. 4a), and with higher placental TAT-1 mRNA levels $\left(r^{2}=0.2978, P=0.0128\right.$, Fig. $\left.4 \mathrm{~b}\right)$. Across all groups, higher placental TAT-1 mRNA levels tended to be associated with higher placental CYP27B1 mRNA levels $\left(r^{2}=0.1491, P=0.0927\right)$, and this was significant in the $\mathrm{C}$ group alone $\left(r^{2}=0.8895, P=0.0014\right)$. Across all groups, lower fetal plasma $25 \mathrm{OHD}_{\text {total }}$ concentration tended to be associated with higher placental TAT-1 mRNA levels $\left(r^{2}=0.19, P=0.0558\right)$, and this was significant in the PI40 group alone $\left(r^{2}=0.5188, P=0.0439\right)$.

\section{Associations of materno-placental-fetal vitamin D with fetal physiology}

\section{Fetal and placental weight}

Fetal and placental weights were not different between diet groups. Across all groups, higher placental CYP27B1 mRNA was associated with higher fetal weight $\left(r^{2}=0.2398\right.$, $P=0.0242)$. Across all groups and in the control group alone, higher maternal plasma $250 H D$ concentration was associated with higher placental weight (all groups: $r^{2}=0.1900$, $P=0.0426$; control: $r^{2}=0.6392, P=0.0309$ ), but there was no association between fetal plasma $25 \mathrm{OHD}$ concentration and fetal-placental weight. Across all groups, a higher maternal blood $\mathrm{Ca}^{2+}$ concentration was associated with lower fetal weight $\left(r^{2}=0.1893, P=0.043\right)$. Across all groups, there was a trend for lower average placentome type $B$ weight 
(a)
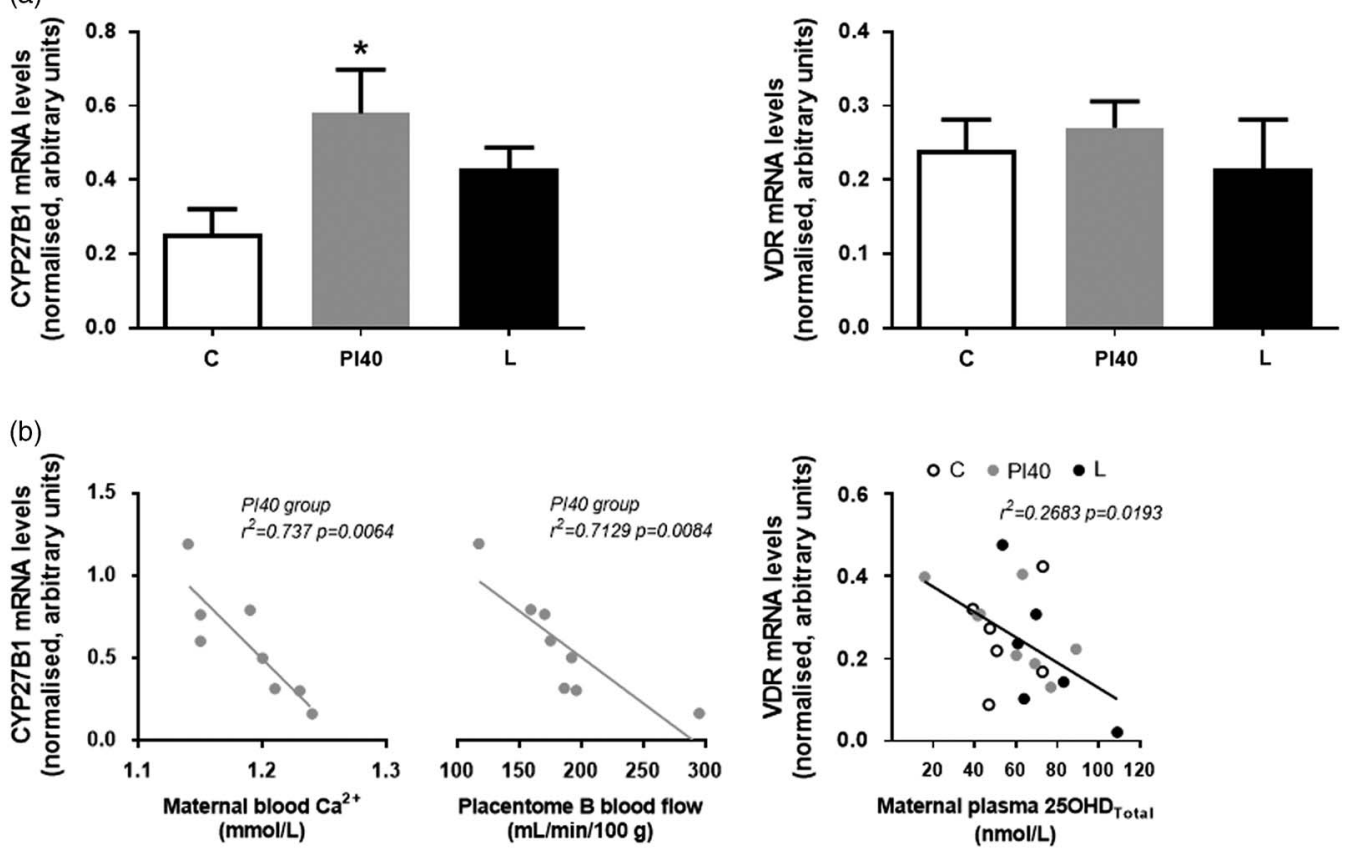

Fig. 2. Effect of maternal undernutrition on CYP27B1 mRNA and vitamin D receptor levels in the placenta. Data are mean \pm S.E.M. (a) CYP27B1 and VDR mRNA levels in the placenta ${ }^{*} P<0.05$, compared with the control group; (b) association of CYP27B1 and VDR mRNA levels with maternal and placental factors by linear regression. C, control (open bars/symbols); PI40, peri-implantation undernutrition (grey bars/symbols); L, late gestation undernutrition (solid bar/symbols) groups.

(a)

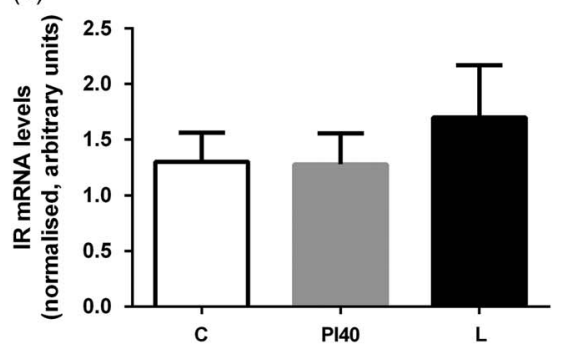

(b)

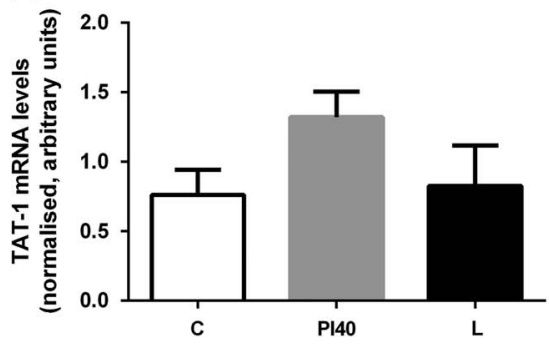

(c)

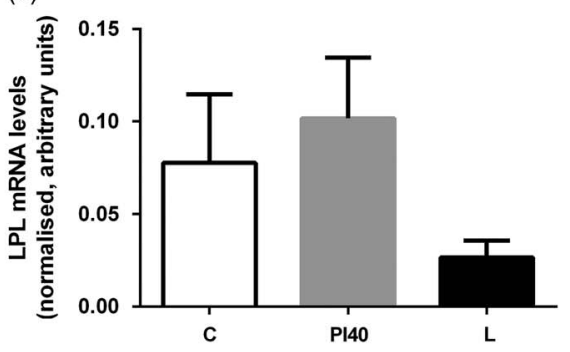

Fig. 3. Effect of maternal undernutrition on transport and growth gene mRNA in the placenta. Data are mean \pm s.E.M. Levels of $(a)$ insulin receptor (IR); (b) T-type amino acid transporter-1 (TAT-1); and (c) lipoprotein lipase (LPL) mRNA in the placenta. C, control (open bars); PI40, peri-implantation undernutrition (grey bars); L, late gestation undernutrition (solid bar) groups.

to be associated with higher placental VDR mRNA levels $\left(r^{2}=0.1488, P=0.0841\right)$.

\section{Cardiovascular control and skeletal muscle development}

Type B placentome blood flow was not different between diet groups $(\mathrm{ml} / \mathrm{min} / 100 \mathrm{~g}$ tissue. C: $159.976 \pm 12.904$; PI40: $181.700 \pm 16.413$; L: $169.813 \pm 27.720, n=5)$. There was no association of type B placentome blood flow with maternal or fetal plasma $25 \mathrm{OHD}_{\text {total }}$. Across all groups, higher fetal $25 \mathrm{OHD}_{\text {total }}$ concentration was associated with higher total myofibre density $\left(r^{2}=0.1876, P=0.0498\right)$ and higher capillary density $\left(r^{2}=0.2119, P=0.0357\right)$ in the fetal triceps brachii muscle (Fig. 5). Baseline cardiovascular measurements and plasma angiotensin II concentration for this cohort have been published previously, ${ }^{2}$ but are reported here for ease of reading and for experimental group sizes reported on in this paper. As previously reported, ${ }^{2}$ there was no difference between diet groups in fetal baseline plasma angiotensin II

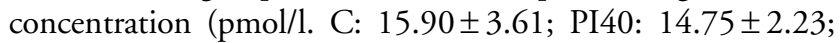
$\mathrm{L}: 16.26 \pm 2.92)$, mean arterial blood pressure $(\mathrm{mmHg}$. C:

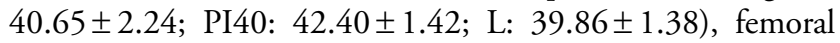

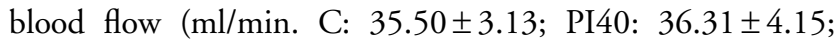
L: $37.85 \pm 8.04)$, carotid blood flow $(\mathrm{ml} / \mathrm{min}$. C: $80.64 \pm$ 6.56; PI40: 81.56 5.80; L: 79.39 \pm 11.90$)$ and heart rate (beats/min. C: $167.14 \pm 7.71$; PI40: $172.48 \pm 2.38$; $\mathrm{L}: 172.07 \pm 3.74)$. There was no association between either fetal in vivo cardiovascular measurements or fetal plasma 


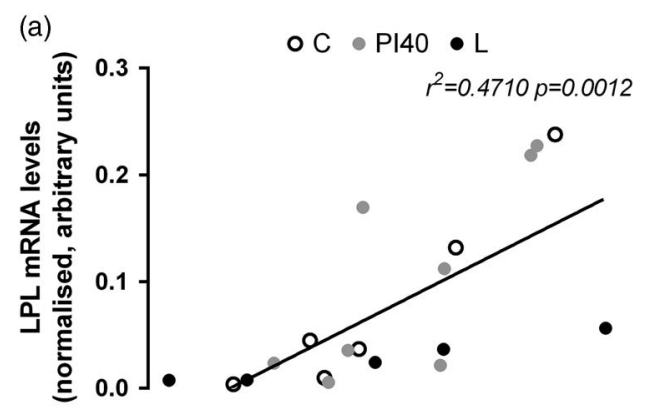

(b)

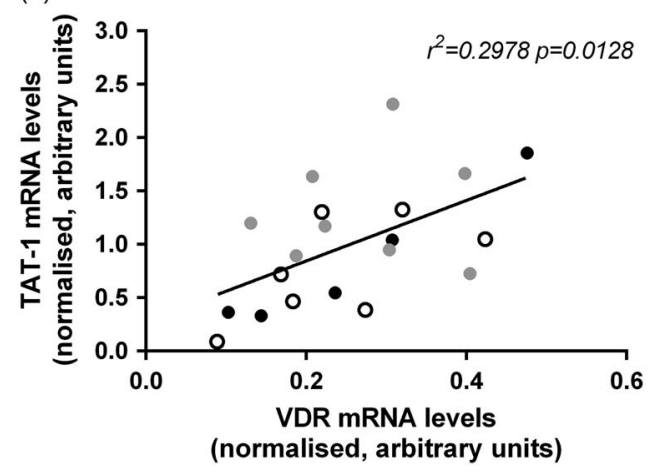

Fig. 4. Association of mRNA levels for transport genes and vitamin $\mathrm{D}$ receptor (VDR) in the placenta. Association of placental levels of VDR mRNA with (a) lipoprotein lipase (LPL) and (b) T-type amino acid transporter-1 (TAT-1) mRNA levels were assessed by linear regression. C, control (open symbols); PI40, peri-implantation undernutrition (grey symbols); L, late gestation undernutrition (solid symbols) groups.

angiotensin II concentration and fetal plasma 25OHD concentration.

\section{Discussion}

We have shown that both early gestation (peri-implantation) and late gestation maternal undernutrition result in lower fetal 25OHD plasma concentrations in late gestation. A number of associations have been made between maternal vitamin $\mathrm{D}$ status and offspring body composition and cardiovascular function. ${ }^{25,28,29}$ Thus our observation of an association between fetal vitamin $\mathrm{D}$ status and fetal skeletal muscle structure, and between the placental mRNA for VDR and nutrient transporter genes, suggests additional mechanisms through which fetal physiology may be influenced in this undernutrition model.

The observed maternal-fetal plasma gradient in concentration of 25OHD is similar to that reported in humans, ${ }^{14}$ agrees with previous studies in sheep ${ }^{57}$ and is consistent with the idea that $25 \mathrm{OHD}$ diffuses across the placenta. The association of higher maternal plasma $25 \mathrm{OHD}$ with higher fetal plasma $25 \mathrm{OHD}$ concentration was a trend, and this probably reflects the modest cohort size by comparison with many human studies, and a nutritional challenge in critical discrete windows
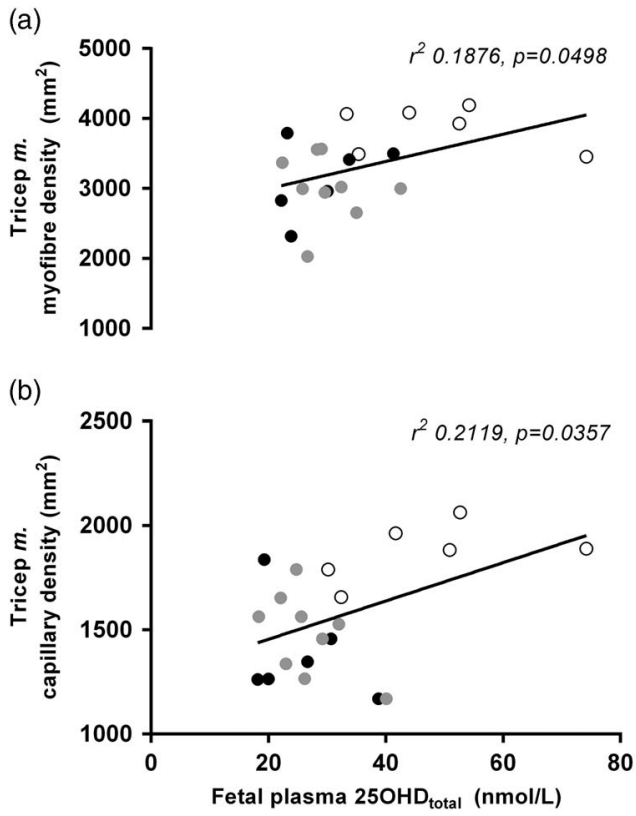

Fig. 5. Association of fetal skeletal muscle structure with plasma $25 \mathrm{OHD}$ status. The association of fetal plasma $25 \mathrm{OHD}_{\text {total }}$ with tricep muscle (a) myofibre density and (b) capillary density was assessed by linear regression. C, control (open symbols); PI40, peri-implantation undernutrition (grey symbols); L, late gestation undernutrition (solid symbols) groups.

of pregnancy. Our reported maternal plasma $25 \mathrm{OHD}_{2}$ and $25 \mathrm{OHD}_{3}$ concentrations were of a similar magnitude to those previously reported for 36-48-month old non-pregnant, nonlactating female sheep $(-34$ and $-32 \mathrm{nmol} / \mathrm{L}$, respectively) housed outdoors in the United States with a reported unrestricted exposure to sunlight. ${ }^{58}$ Sheep can produce vitamin $\mathrm{D}_{3}$ (cholecalciferol) in response to ultraviolet B (UVB) irradiation of 7-dehydrocholesterol in skin, ${ }^{58,59}$ however our sheep were housed indoors and fed a complete pelleted diet which was supplemented with vitamin $\mathrm{D}_{3}$ according to standard practice and guidelines. ${ }^{60}$ The plasma concentration of $25 \mathrm{OHD}_{2}$ is substantially higher than that detected in humans and is likely to originate from ergosterol in the naturally occurring fungi content of plant matter (e.g. grass meal) which when exposed to UVB irradiation produces vitamin $\mathrm{D}_{2}$ (ergocalciferol). ${ }^{61} \mathrm{We}$ report a fetal-maternal gradient in blood concentrations of ionized calcium which is in agreement with human data from second trimester pregnancies and consistent with the involvement of active processes in transplacental calcium transfer. ${ }^{13,62}$ In humans, a prenatal high dose oral vitamin $\mathrm{D}_{3}$ supplementation (35,000 IU/week) from 26 to 29 weeks of gestation elevated cord blood total calcium. ${ }^{63}$ However, our data do not show a relationship between $25 \mathrm{OHD}$ status and whole blood ionized calcium concentration in the mother or fetus.

Maternal plasma $25 \mathrm{OHD}_{2}$ or $25 \mathrm{OHD}_{3}$ concentrations were not different between dietary groups, which suggested that dietary provision of vitamin $\mathrm{D}_{2}$ or $\mathrm{D}_{3}$ to the mother was 
still adequate. However, fetal plasma concentration of $25 \mathrm{OHD}_{2}$ and $25 \mathrm{OHD}_{3}$ were lower in early and late gestation maternal undernutrition groups compared with the control group, which suggests that placental transport or handling of vitamin D may have been altered. Our observation that placental CYP27B1 mRNA levels were higher in the group exposed to maternal undernutrition in early pregnancy (PI40 group) suggests a possible molecular mechanism through which more placental conversion of $25 \mathrm{OHD}$ to $1,25(\mathrm{OH})_{2} \mathrm{D}$ might reduce the amount of $25 \mathrm{OHD}$ that is transported to these fetuses. CYP27B1 is expressed in maternal and fetal portions of the placenta ${ }^{13}$ although we were unable to measure the differential expression between maternal and fetal placenta in the current study. CYP27B1 mRNA may not reflect protein levels, but it was not possible to measure these in our tissues. However, this mechanism does not explain the lower fetal plasma $25 \mathrm{OHD}$ concentration in the $\mathrm{L}$ group. It remains possible that lower fetal $25 \mathrm{OHD}$ concentration could be due to increased conversion to $24,25-(\mathrm{OH})_{2} \mathrm{D}$ in the placenta or fetus.

The mechanism underlying altered placental CYP27B1 mRNA levels in PI 40 animals appears to be more complicated than altered maternal vitamin $\mathrm{D}$ concentration as this did not differ between the groups. Unlike previous observations in humans, ${ }^{32}$ higher maternal 25OHD across all groups was not associated with higher placental CY27B1 mRNA levels. Instead, alteration in another maternal dietary component, or a placental adaptation to it, may be responsible for driving this change in CYP27B1 expression. In PI40 animals, increased maternal blood $\mathrm{Ca}^{2+}$ concentration was associated with decreased placental CYP27B1 mRNA levels which may be due to a direct effect of calcium on the expression of CYP27B1 mRNA, or to changes in parathyroid hormone and/or calcitonin which are known regulators of CYP27B1 transcription. ${ }^{64}$ We observed a strong association between higher placental CYP27B1 mRNA levels and lower type B placentome blood flow in the PI40 group. This might seem counterintuitive as vitamin $\mathrm{D}$ is linked to improved angiogenesis and vasorelaxation, ${ }^{65}$ and we can only speculate that higher CYP27B1 mRNA levels could mean increased availability of $1,25(\mathrm{OH})_{2} \mathrm{D}$ to the placenta. In addition, a 'snap-shot' measurement of blood flow and gene expression status at a single point in gestation does not allow us to distinguish between acute and adaptive/compensatory changes. Overall, we cannot infer causality from such associations and further studies are needed to establish underlying mechanisms.

Maternal undernutrition had no effect on placental mRNA levels of VDR and the small set of placental growth and nutrient transport genes that were assessed. Extension of this work would need to consider measurement of the multiple components of the insulin-like growth factor axis (peptides, receptor and binding proteins). Our recent work suggests that LPL and TAT-1 mRNA levels are approximately two-fold greater in the fetal compared with the maternal portion of the sheep placentome. ${ }^{66}$ In addition, TAT-1 is present in the human basal (fetal-facing) membrane where it may play an important part in efflux of amino acids to the fetus. ${ }^{67}$ Therefore in the present study, it is possible that any effects of maternal undernutrition on mRNA levels in maternal or fetal-placental tissue were masked by our having analysed whole placentomes.

Recent studies in adolescent human pregnancies suggest that fetal $1,25(\mathrm{OH})_{2} \mathrm{D}$ is a positive regulator, whereas maternal and fetal $25 \mathrm{OHD}$ are negative regulators of placental VDR expression. ${ }^{33}$ Our finding, regardless of diet group, of a small association between higher maternal 25OHD and lower placental VDR mRNA supports this idea in part. On the other hand, we did not find a clear link between fetal vitamin D and placental VDR mRNA. We observed that a higher ratio of fetal-to-maternal 25OHD concentration was associated with higher placental VDR mRNA in the PI40 group alone. It is highly speculative, but if the relatively higher fetal $25 \mathrm{OHD}$ concentration meant higher fetal $1,25(\mathrm{OH})_{2} \mathrm{D}$ concentration then it would support the idea that higher fetal $1,25(\mathrm{OH})_{2} \mathrm{D}$ predicts higher placental VDR expression. ${ }^{33}$

Across all diet groups, higher maternal plasma $25 \mathrm{OHD}_{\text {total }}$ was associated very modestly with higher placental weight which supports broadly the idea of a placental adaptation to maternal vitamin D status. Placental VDR levels may be linked to regulation of placental nutrient transport. ${ }^{33,41}$ Our observation of a modest association of higher VDR mRNA with higher TAT-1 and LPL mRNA in the placenta appears to be consistent with the potential presence of VDREs in TAT-1 and LPL genes. ${ }^{43,48}$ The VDR-RXR complex binds to VDREs to regulate gene expression. ${ }^{68}$ The very modest observed associations of higher placental CYP27B1 mRNA with higher TAT-1 mRNAs (trend) and with higher fetal weight are intriguing. We can only speculate that if higher CY27B1 leads to higher 1,25 $(\mathrm{OH})_{2} \mathrm{D}$ in the placenta, then it may, via the VDRE in the TAT-1 gene lead to higher TAT-1 expression.

In this study we have shown a very modest association of lower fetal plasma 25OHD concentration with lower fetal skeletal muscle fibre density in the triceps brachii muscle. This observation extends our previous report in these animals that myofibre and capillary density are reduced following maternal undernutrition in early and late gestation. ${ }^{10}$ The VDR is present in isolated skeletal muscle cells ${ }^{69}$ and whole muscle,${ }^{21}$ and vitamin $\mathrm{D}$ affects skeletal muscle proliferation, differentiation and myotube size. ${ }^{70}$ VDR null mice had $20 \%$ smaller skeletal muscle fibre size, increased skeletal muscle expression of myogenic transcription factors myf5, E2A and myogenin, and inappropriate expression of embryonic and neonatal type myosin heavy chain $(\mathrm{MHC}) .^{71}$ In addition, in fish larvae, higher dietary vitamin $\mathrm{D}_{3}$ caused white muscle fibre hypertrophy and regulated Myf5, MyoD1, myogenin and MHC gene expression. ${ }^{72}$ In humans, poor adult vitamin $\mathrm{D}$ status is related to myopathy and associated with structural and electrophysiological muscle changes ${ }^{73,74}$ and maternal $25 \mathrm{OHD}$ status is positively associated with offspring grip strength at 4 years of age. ${ }^{28}$ These findings together with our current observations point towards a potential role for vitamin $\mathrm{D}$ status in pregnancy on life-long muscle function. 
We have shown a very modest association of lower fetal plasma 25OHD concentrations with lower fetal capillary density in the triceps brachii muscle. The VDR has been identified in vascular endothelial and smooth muscle and linked to angiogenesis and proliferation. ${ }^{75,76}$ Vitamin $\mathrm{D}_{3}$ promoted angiogenesis in endothelial colony-forming cells from cord blood. ${ }^{77}$ In the present study, there were no other links observed between fetal 25OHD and our measures of fetal cardiovascular function in vivo.

In conclusion, this study has provided novel insight into the effect of maternal total calorific restriction during critical windows of gestation on late gestation fetal vitamin $\mathrm{D}$ status, which may be mediated in part by changes to placental vitamin $\mathrm{D}$ handling via CYP27B1. Our findings do not support a role for maternal-fetal vitamin $\mathrm{D}$ in mediating the fetal cardiovascular adaptations in this model of maternal nutrient restriction. Our data suggest that a reasonably small part of reduced fetal skeletal myofibre and capillary density may be accounted for by lower fetal vitamin D levels; future systematic investigations of the effect of specific vitamin $\mathrm{D}$ deficiency during pregnancy on cardiovascular control and growth during fetal life will be required. These should include measurement of $1,25(\mathrm{OH})_{2} \mathrm{D}$, which is synthesized by the fetus, ${ }^{14,15}$ and key components of vitamin D regulation and signalling (e.g. VDR and CYP27B1 genes) in muscle and cardiovascular tissues. Our regression analysis suggests that a small part of the variation in genes involved in nutrient transport in the placenta may be due to variation in VDR levels, but the findings do offer insight into the potential role of the placenta in transducing information on vitamin $\mathrm{D}$ status to the fetus. Fetal adaptive physiological responses to changes in the maternal environment are now thought to underpin the risk of many adult diseases, including metabolic and cardiovascular disease. ${ }^{1}$ Numerous associations have been made between vitamin $\mathrm{D}$ status and disease (including metabolic and cardiovascular); our findings now add important information to the impact of maternal nutrition on determining fetal vitamin D status, the role of the placenta, and the potential impact on the fetus. This knowledge is of potential importance to both agriculture and clinical obstetrics, which have similar concerns about living conditions (i.e. latitude and sunshine exposure) and diet before and during pregnancy.

\section{Acknowledgements}

The authors are grateful to staff at the Biological Services Unit, Royal Veterinary College and the Biological Research Facility, University of Southampton for their expert animal care. They are grateful to D. Noakes for his long-term collaboration on these sheep studies.

Authors' Contributions: L.R.G. and J.K.C. formulated the research question, L.R.G. and M.A.H. designed the study, J.K.C., M.R.H., W.D.F. and J.C.Y.T. analysed all the samples; L.R.G., J.K.C. and K.P. analysed the data; and L.R.G. wrote the manuscript with input from all authors.

\section{Financial Support}

This work was supported by a Biotechnology and Biological Sciences Research Council grant (L.R.G. and M.A.H. grant number D17858), and The Gerald Kerkut Trust (L.R.G., no grant number). M.A.H. is supported by the British Heart Foundation. Biotechnology and Biological Sciences Research Council and the British Heart Foundation had no role in the design, analysis or writing of this article.

\section{Conflicts of Interest}

None.

\section{Ethical Standards}

The authors assert that all procedures contributing to this work comply with the ethical standards of the relevant national guides on the care and use of laboratory animals (UK Animals (Scientific Procedures) Act 1986) and have been approved by the institutional committee (Science Review Group, a subcommittee of the Animal Welfare and Ethical Review Body, University of Southampton).

\section{References}

1. Bateson P, Gluckman P, Hanson M. The biology of developmental plasticity and the predictive adaptive response hypothesis. J Physiol. 2014; 592(Pt 11), 2357-2368.

2. Braddick LM, Burrage DM, Cleal JK, et al. The lack of impact of peri-implantation or late gestation nutrient restriction on ovine fetal renal development and function. J Dev Orig Health Dis. 2011; 2, 236-249.

3. Burrage DM, Braddick L, Cleal JK, et al. The late gestation fetal cardiovascular response to hypoglycaemia is modified by prior peri-implantation undernutrition in sheep. J Physiol. 2009; 587(Pt 3), 611-624.

4. Cleal JK, Poore KR, Boullin JP, et al. Mismatched pre- and postnatal nutrition leads to cardiovascular dysfunction and altered renal function in adulthood. Proc Natl Acad Sci USA. 2007; 104, 9529-9533.

5. Edwards LJ, Simonetta G, Owens JA, Robinson JS, McMillen IC. Restriction of placental and fetal growth in sheep alters fetal blood pressure responses to angiotensin II and captopril. J Physiol (Lond). 1999; 515(Pt 3), 897-904.

6. Edwards LJ, McMillen IC. Periconceptional nutrition programs development of the cardiovascular system in the fetal sheep. $\mathrm{Am} \mathrm{J}$ Physiol Regul Integr Comp Physiol. 2002; 283, R669-R679.

7. Hawkins P, Steyn C, Ozaki T, et al. Effect of maternal undernutrition in early gestation on ovine fetal blood pressure and cardiovascular reflexes. Am J Physiol. 2000; 279, R340-R348.

8. Hawkins P, Steyn C, McGarrigle HH, et al. Cardiovascular and hypothalamic-pituitary-adrenal axis development in late gestation fetal sheep and young lambs following modest maternal nutrient restriction in early gestation. Reprod Fertil Dev. 2000; 12, 443-456.

9. Torrens C, Snelling TH, Chau R, et al. Effects of pre- and periconceptional undernutrition on arterial function in adult 
female sheep are vascular bed dependent. Exp Physiol. 2009; 94, 1024-1033.

10. Costello PM, Rowlerson A, Astaman NA, et al. Peri-implantation and late gestation maternal undernutrition differentially affect fetal sheep skeletal muscle development. J Physiol. 2008; 586, 2371-2380.

11. Lie S, Morrison JL. Impact of periconceptional and preimplantation undernutrition on factors regulating myogenesis and protein synthesis in muscle of singleton and twin fetal sheep. Physiol Rep. 2015; 3, e12495.

12. Lie S, Morrison JL, Williams-Wyss O, et al. Periconceptional undernutrition programs changes in insulin-signaling molecules and microRNAs in skeletal muscle in singleton and twin fetal sheep. Biol Reprod. 2014; 90, 5.

13. Liu NQ, Hewison M. Vitamin D, the placenta and pregnancy. Arch Biochem Biophys. 2012; 523, 37-47.

14. Salle BL, Delvin EE, Lapillonne A, Bishop NJ, Glorieux FH. Perinatal metabolism of vitamin D. Am J Clin Nutr. 2000; 71(Suppl. 5), 1317S-1324S.

15. Ross R, Halbert K, Tsang RC. Determination of the production and metabolic clearance rates of 1,25-dihydroxyvitamin D3 in the pregnant sheep and its chronically catheterized fetus by primed infusion technique. Pediatr Res. 1989; 26, 633-638.

16. Hollis BW, Wagner CL. Vitamin D and pregnancy: skeletal effects, nonskeletal effects, and birth outcomes. Calcif Tissue Int. 2013; 92, 128-139.

17. Eyles D, Burne T, McGrath J. Vitamin D in fetal brain development. Semin Cell Dev Biol. 2011; 22, 629-636.

18. Kovacs CS. Bone development and mineral homeostasis in the fetus and neonate: roles of the calciotropic and phosphotropic hormones. Physiol Rev. 2014; 94, 1143-1218.

19. Wang Y, Zhu J, DeLuca HF. Where is the vitamin D receptor? Arch Biochem Biophys. 2012; 523, 123-133.

20. Pilz S, Tomaschitz A, Marz W, et al. Vitamin D, cardiovascular disease and mortality. Clin Endocrinol (Oxf). 2011; 75, 575-584.

21. Girgis CM, Mokbel N, Minn CK, et al. The vitamin D receptor (VDR) is expressed in skeletal muscle of male mice and modulates 25-hydroxyvitamin D (25OHD) uptake in myofibers. Endocrinology. 2014; 155, 3227-3237.

22. Pludowski P, Holick MF, Pilz S, et al. Vitamin D effects on musculoskeletal health, immunity, autoimmunity, cardiovascular disease, cancer, fertility, pregnancy, dementia and mortality - a review of recent evidence. Autoimmun Rev. 2013; 12, 976-989.

23. Mahon P, Harvey N, Crozier S, et al. Low maternal vitamin D status and fetal bone development: cohort study. J Bone Miner Res. 2010; 25, 14-19.

24. Dror DK, Allen LH. Vitamin D inadequacy in pregnancy: biology, outcomes, and interventions. Nutr Rev. 2010; 68, 465-477.

25. Tare M, Emmett SJ, Coleman HA, et al. Vitamin D insufficiency is associated with impaired vascular endothelial and smooth muscle function and hypertension in young rats. J Physiol. 2011; 589(Pt 19), 4777-4786.

26. Morris GS, Zhou Q, Hegsted M, Keenan MJ. Maternal consumption of a low vitamin D diet retards metabolic and contractile development in the neonatal rat heart. J Mol Cell Cardiol. 1995; 27, 1245-1250.

27. Gezmish O, Tare M, Parkington HC, et al. Maternal vitamin D deficiency leads to cardiac hypertrophy in rat offspring. Reprod Sci. 2010; 17, 168-176.
28. Harvey NC, Moon RJ, Sayer AA, et al. Maternal antenatal vitamin $\mathrm{D}$ status and offspring muscle development: findings from the Southampton Women's Survey. J Clin Endocrinol Metab. 2014; 99, 330-337.

29. Crozier SR, Harvey NC, Inskip HM, et al. Maternal vitamin D status in pregnancy is associated with adiposity in the offspring: findings from the Southampton Women's Survey. Am J Clin Nutr. 2012; 96, 57-63.

30. Lewis RM, Cleal JK, Hanson MA. Review: placenta, evolution and lifelong health. Placenta. 2012; 33(Suppl.), S28-S32.

31. Liu NQ, Ouyang Y, Bulut Y, et al. Dietary vitamin D restriction in pregnant female mice is associated with maternal hypertension and altered placental and fetal development. Endocrinology. 2013; 154, 2270-2280.

32. O'Brien KO, Li S, Cao C, et al. Placental CYP27B1 and CYP24A1 expression in human placental tissue and their association with maternal and neonatal calcitropic hormones. J Clin Endocrinol Metab. 2014; 99, 1348-1356.

33. Young BE, Cooper EM, McIntyre AW, et al. Placental vitamin D receptor (VDR) expression is related to neonatal vitamin $\mathrm{D}$ status, placental calcium transfer, and fetal bone length in pregnant adolescents. FASEB J. 2014; 28, 2029-2037.

34. Nguyen TP, Yong HE, Chollangi T, et al. Placental vitamin D receptor expression is decreased in human idiopathic fetal growth restriction. J Mol Med. 2015; 93, 795-805.

35. Knabl J, Huttenbrenner R, Hutter S, et al. Gestational diabetes mellitus upregulates vitamin $\mathrm{D}$ receptor in extravillous trophoblasts and fetoplacental endothelial cells. Reprod Sci. 2015; $22,358-366$.

36. Hiden U, Glitzner E, Hartmann M, Desoye G. Insulin and the IGF system in the human placenta of normal and diabetic pregnancies. J Anat. 2009; 215, 60-68.

37. Calle C, Maestro B, Garcia-Arencibia M. Genomic actions of 1,25-dihydroxyvitamin D3 on insulin receptor gene expression, insulin receptor number and insulin activity in the kidney, liver and adipose tissue of streptozotocin-induced diabetic rats. BMC Mol Biol. 2008; 9, 65.

38. Maestro B, Davila N, Carranza MC, Calle C. Identification of a vitamin $\mathrm{D}$ response element in the human insulin receptor gene promoter. J Steroid Biochem Mol Biol. 2003; 84, 223-230.

39. Cetin I. Placental transport of amino acids in normal and growthrestricted pregnancies. Eur J Obstet Gynecol Reprod Biol. 2003; 110(Suppl. 1), S50-S54.

40. Cleal JK, Lewis RM. The mechanisms and regulation of placental amino acid transport to the human foetus. J Neuroendocrinol. 2008; 20, 419-426.

41. Cleal JK, Day PE, Simner CL, et al. Placental amino acid transport may be regulated by maternal vitamin $\mathrm{D}$ and vitamin D-binding protein: results from the Southampton Women's Survey. Br J Nutr. 2015; 113, 1903-1910.

42. Quandt K, Frech K, Karas H, Wingender E, Werner T. MatInd and MatInspector: new fast and versatile tools for detection of consensus matches in nucleotide sequence data. Nucleic Acids Res. 1995; 23, 4878-4884.

43. Ramagopalan SV, Heger A, Berlanga AJ, et al. A ChIP-seq defined genome-wide map of vitamin $\mathrm{D}$ receptor binding: associations with disease and evolution. Genome Res. 2010; 20, 1352-1360. 
44. Magnusson-Olsson AL, Hamark B, Ericsson A, et al. Gestational and hormonal regulation of human placental lipoprotein lipase. J Lipid Res. 2006; 47, 2551-2561.

45. Qiao L, Guo Z, Bosco C, et al. Maternal high-fat feeding increases placental lipoprotein lipase activity by reducing SIRT1 expression in mice. Diabetes. 2015; 64, 3111-3120.

46. Huang Y, Li X, Wang M, et al. Lipoprotein lipase links vitamin $\mathrm{D}$, insulin resistance, and type 2 diabetes: a cross-sectional epidemiological study. Cardiovasc Diabetol. 2013; 12, 17.

47. Vu D, Ong JM, Clemens TL, Kern PA. 1,25-dihydroxyvitamin $\mathrm{D}$ induces lipoprotein lipase expression in 3T3-L1 cells in association with adipocyte differentiation. Endocrinology. 1996; 137, 1540-1544.

48. Bey L, Etienne J, Tse C, et al. Cloning, sequencing and structural analysis of 976 base pairs of the promoter sequence for the rat lipoprotein lipase gene. Comparison with the mouse and human sequences. Gene. 1998; 209, 31-38.

49. Agricultural and Food Research Council. Energy and Protein Requirements of Ruminants. AFRC: Wallingford, UK, 1993.

50. Vatnick I, Schoknecht PA, Darrigrand R, Bell AW. Growth and metabolism of the placenta after unilateral fetectomy in twin pregnant ewes. J Dev Physiol. 1991; 15, 351-356.

51. Zhang S, Barker P, Botting KJ, et al. Early restriction of placental growth results in placental structural and gene expression changes in late gestation independent of fetal hypoxemia. Physiol Rep. 2016; 4, e13049.

52. Heymann MA, Payne BD, Hoffman JI, Rudolph AM. Blood flow measurements with radionuclide-labeled particles. Prog Cardiovasc Dis. 1977; 20, 55-79.

53. Thein E, Raab S, Harris AG, et al. Comparison of regional blood flow values measured by radioactive and fluorescent microspheres. Eur Surg Res. 2002; 34, 215-223.

54. Snellman G, Melhus H, Gedeborg R, et al. Determining vitamin D status: a comparison between commercially available assays. PLoS One. 2010; 5, e11555.

55. Owens DJ, Webber D, Impey SG, et al. Vitamin D supplementation does not improve human skeletal muscle contractile properties in insufficient young males. Eur J Appl Physiol. 2014; 114, 1309-1320.

56. Bustin SA, Benes V, Garson JA, et al. The MIQE guidelines: minimum information for publication of quantitative real-time PCR experiments. Clin Chem. 2009; 55, 611-622.

57. Paulson SK, DeLuca HF, Battaglia F. Plasma levels of vitamin D metabolites in fetal and pregnant ewes. Proc Soc Exp Biol Med. 1987; 185, 267-271.

58. Horst RL, Littledike ET, Riley JL, Napoli JL. Quantitation of vitamin $\mathrm{D}$ and its metabolites and their plasma concentrations in five species of animals. Anal Biochem. 1981; 116, 189-203.

59. Dittmer KE, Thompson KG. Vitamin D metabolism and rickets in domestic animals: a review. Vet Pathol. 2011; 48, 389-407.

60. National Research Council of the National Academies. Nutrient Requirements of Small Ruminants: Sheep, Goats, Cervids, and New World Camilids. 2007. National Academies Press: Washington, DC.

61. Japelt RB, Jakobsen J. Vitamin D in plants: a review of occurrence, analysis, and biosynthesis. Front Plant Sci. 2013; 4, 136.
62. Moniz CF, Nicolaides KH, Tzannatos C, Rodeck CH. Calcium homeostasis in second trimester fetuses. J Clin Pathol. 1986; 39, 838-841.

63. Harrington J, Perumal N, Al MA, Baqui A, Roth DE. Vitamin D and fetal-neonatal calcium homeostasis: findings from a randomized controlled trial of high-dose antenatal vitamin D supplementation. Pediatr Res. 2014; 76, 302-309.

64. Anderson PH, O'Loughlin PD, May BK, Morris HA. Quantification of mRNA for the vitamin D metabolizing enzymes CYP27B1 and CYP24 and vitamin D receptor in kidney using real-time reverse transcriptase- polymerase chain reaction. J Mol Endocrinol. 2003; 31, 123-132.

65. Gernand AD, Bodnar LM, Klebanoff MA, Parks WT, Simhan HN. Maternal serum 25-hydroxyvitamin D and placental vascular pathology in a multicenter US cohort. Am J Clin Nutr. 2013; 98, 383-388.

66. Naftel J, Carr DJ, Aitken RP, et al. The effect of adenovirusVEGF gene therapy on placental nutrient transport mechanisms in an ovine model of intrauterine growth restriction. Proceedings of the Physiological Society, 2014, 37th Congress of IUPS (Birmingham, UK) (2013) Proc 37th IUPS.

67. Cleal JK, Glazier JD, Ntani G, et al. Facilitated transporters mediate net efflux of amino acids to the fetus across the basal membrane of the placental syncytiotrophoblast. J Physiol. 2011; 589(Pt 4), 987-997.

68. Carlberg C, Campbell MJ. Vitamin D receptor signaling mechanisms: integrated actions of a well-defined transcription factor. Steroids. 2013; 78, 127-136.

69. Girgis CM, Clifton-Bligh RJ, Hamrick MW, Holick MF, Gunton JE. The roles of vitamin D in skeletal muscle: form, function, and metabolism. Endocr Rev. 2013; 34, 33-83.

70. Girgis CM, Clifton-Bligh RJ, Mokbel N, Cheng K, Gunton JE. Vitamin D signaling regulates proliferation, differentiation, and myotube size in C2C12 skeletal muscle cells. Endocrinology. 2014; 155, 347-357.

71. Endo I, Inoue D, Mitsui T, et al. Deletion of vitamin D receptor gene in mice results in abnormal skeletal muscle development with deregulated expression of myoregulatory transcription factors. Endocrinology. 2003; 144, 5138-5144.

72. Alami-Durante H, Cluzeaud M, Bazin D, Mazurais D, Zambonino-Infante JL. Dietary cholecalciferol regulates the recruitment and growth of skeletal muscle fibers and the expressions of myogenic regulatory factors and the myosin heavy chain in European sea bass larvae. J Nutr. 2011; 141, 2146-2151.

73. Ceglia L, Harris SS. Vitamin D and its role in skeletal muscle. Calcif Tissue Int. 2012; 92, 151-162.

74. Polly P, Tan TC. The role of vitamin D in skeletal and cardiac muscle function. Front Physiol. 2014; 5, 145.

75. Razzaque MS. The dualistic role of vitamin D in vascular calcifications. Kidney Int. 2011; 79, 708-714.

76. Valdivielso JM, Coll B, Fernandez E. Vitamin D and the vasculature: can we teach an old drug new tricks? Expert Opin Ther Targets. 2009; 13, 29-38.

77. Grundmann M, Haidar M, Placzko S, et al. Vitamin D improves the angiogenic properties of endothelial progenitor cells. $\mathrm{Am} \mathrm{J}$ Physiol Cell Physiol. 2012; 303, C954-C962. 